\title{
ENVIRONMENTAL IMPACT OF THE STORED DUST-LIKE ZINC AND IRON CONTAINING WASTES
}

\author{
Tatyana A. Lytaeva' ${ }^{1}$, Aleksandr E. Isakov ${ }^{1}$ \\ 1 Saint Petersburg Mining University, $21^{\text {st }}$ line V.O. 2, Saint Petersburg, 199106, Russian Federation, e-mail: \\ omnp@spmi.ru, ecolab@spmi.ru
}

Received: 2017.02 .13

Accepted: 2017.03 .07

Published: 2017.05.02

\begin{abstract}
Effects of the stored dust-like zinc and iron containing wastes of the mining and processing industry consist of the loss of valuable components and environmental pollution. Thus, the goals of the research were to analyse ecological conditions under the technogenic impact at the waste storage site and to study transformations of the stored dust-like zinc and iron containing wastes in the active supergene zone. Materials are based on the physical laboratory-modelled infiltration of the atmospheric precipitation waters through the zinc and iron containing wastes. Methods include systematically-structured analysis of wastes and disposal site and laboratory techniques (X-ray fluorescence and atomic emission spectrometry). On the basis of laboratory research and field observations of the environmental components in the impact area of the storage of dust-like zinc and iron containing wastes, the article describes regularities of formation of hydrogeochemical halos of contamination by heavy metals and iron. The results also include the description of changes in physico-chemical groundwater composition under the storage area.
\end{abstract}

Keywords: waste storage, ecological situation, infiltration of contaminants, fluxes and halos of pollution.

\section{INTRODUCTION}

Environmental pollution by industrial wastes is one of the major contemporary issues. Enterprises of metallurgy, mechanical engineering, fuel and energy complex make the largest negative contribution to environmental pollution (including heavy metal compounds). At the same time, environmental damage caused by waste disposal is more than $60 \%$ of the total damage caused by the industry as a whole [Yaroshenko, 2011; Zhuikova et al., 2015].

The operation of the mining enterprises in the Russian Federation is accompanied by the annual formation of more than 2 billion tons of industrial solid waste, which leads to significant violations and environmental pollution [State report, 2015].

The following natural properties change during mineral deposit mining: forms and parameters of the relief, the landscape structure and visual characteristics of an area [Alekseenko, Pashkevich, 2016; Timofeev et al., 2016]; transit and unloading of ground and surface water [Pashkevich et al., 2015; Roca et al., 2012]; the emergence of new factors of wildlife disturbance; the vegetation destruction [Alekseenko et al., 2017; Bezel', Zhuikova, 2007; Bolshunova et al., 2014; Rikhanov et al., 2011].

The dust-like zinc and iron containing wastes are amongst the most hazardous waste of mining and processing industries because of their finely divided form and polyelement composition. Zinc and iron containing dusts and sludges, which do not meet the waste quality requirements for secondary metallurgy [Beloglazov et al., 2014a, 2014b], stored and accumulated in the landfills [Jalkanen et al., 2005; Machado da Silva, Brehm, 2006]. 


\section{MATERIALS AND METHODS}

The dust of aspiration and gas cleaning systems of the Cherepovets Steel Mill electric furnace production (PJSC "Severstal") is an example of the dust-like zinc and iron containing wastes. The plant forms annually over 10 thousand tons of the dust-like zinc and iron containing wastes that are stored at the enterprise territory. Therefore, by the end of 2016, the volume of accumulated dust wastes of the electric steel production amounted to more than 120 thousand tons.

The impact of external and internal factors on landfilled waste is the main cause of pollutant transfer to the environment. The external factors include precipitation, air currents, surface waters, temperature, the activity of microorganisms; the internal ones include chemical and mineral composition of the wastes, their dispersion, porosity, water permeability [Fomenko, 2006]. The formation of fluxes and halos pollution of environment components happens due to the impact of external and internal factors.

Contamination of the surface air layer with the dust from the waste storage occurs because of waste weathering when stored in open areas, as well as during transportation and unloading. The atmochemical dispersion halo of pollutants forms as a result of dusting in the waste storage area.

The dust emission regime is not constant at a given enterprise. In the winter period (November-March) snow covers a large part of the stored wastes and minimizes dusting; in the summer period dusting increases. Dusting intensity decreases during snow melting and rainfalls due to the heightened humidity.

Taking into account the wind rose of Cherepovets city, pollution of the ground air layer at the landfill of the dust from aspiration and gas cleaning systems of the electric steel production is limited to the territory of the enterprise industrial site. The excess of 0.1 average daily maximum permissible concentration does not occur beyond the border of the sanitary protection zone.

Formation of hydrogeochemical halos and fluxes of pollution occurs because of dissolution (leaching) of waste components with technogenic waters. During the dry storage of wastes, technogenic infiltration waters form under the influence of rain and melted waters. The amount of precipitation, average intensity and duration, $\mathrm{pH}$ and chemical composition are the main factors of their formation [Baldwin et al., 1995]. Accord- ing to "Gidrometbyuro Cherepovets", the annual rainfall in 2015 was $694 \mathrm{~mm}$, the $\mathrm{pH}$ ranged from 3.5 to 6.2 [State report, 2015].

Not only the chemical composition of precipitation but also the composition of stored wastes has an impact on the formation of the composition of technogenic waters. The methods of X-ray fluorescence spectrometry and thermal analysis methods were used to determine the qualitative and quantitative composition of the dust-like zinc and iron containing wastes of the electric furnace production of PJSC "Severstal" [Lytaeva, Pashkevich, 2013]. Table 1 shows the results of analysis of the waste samples.

Components of the dust-like zinc and iron containing wastes of the electric steel production are mainly oxides and insignificantly - sulphides. At the same time, transitions from one form to another are possible. Thus, by the hydrolysis of metal oxides, some of them become hydroxides, and the impact of free carbonic acid leads to the formation of carbonates [Nyirenda, 1991]. In addition, the presence of sulphate ions in melt and atmospheric waters has a significant impact on the formation of technogenic waters, since the interaction with water forms a weak sulphuric acid.

Besides, it should be noted that sulphides are a part of the gangue component of the storage dam that is also oxidized and hydrated to form a weak acid in turn. Thus, sulphuric acid dissolves the metals that make up the wastes [Fomenko, 2006; Baldwin et al., 1995].

Table 1. Chemical composition of the wastes

\begin{tabular}{|c|c|c|}
\hline Sample number & Substance & Content (\%) \\
\hline 1 & $\mathrm{Fe}$ & 35.41 \\
\hline 2 & $\mathrm{Zn}$ & 21.94 \\
\hline 3 & $\mathrm{~Pb}$ & 6.04 \\
\hline 4 & $\mathrm{CaO}$ & 11.4 \\
\hline 6 & $\mathrm{Cd}$ & 1.10 \\
\hline 7 & $\mathrm{Mn}$ & 1.80 \\
\hline 8 & $\mathrm{SiO}_{2}$ & 5.35 \\
\hline 9 & $\mathrm{MgO}$ & 2.26 \\
\hline 16 & $\mathrm{Cu}$ & 0.08 \\
\hline 17 & $\mathrm{Cr}$ & 0.26 \\
\hline 18 & $\mathrm{Sr}$ & 0.05 \\
\hline 19 & $\mathrm{Al}_{2} \mathrm{O}_{3}$ & 0.73 \\
\hline 20 & $\mathrm{Ni}$ & 0.03 \\
\hline 22 & $\mathrm{C}$ & 2.08 \\
\hline 24 & $\mathrm{~S}$ & 1.20 \\
\hline 25 & $\mathrm{P}$ & 0.10 \\
\hline
\end{tabular}


The character of filtration flow of rainwater and meltwater, migration of water-soluble forms of metal compounds from the stored wastes to soils and groundwater also depend on the geological and hydrological conditions of the hosting environment, the chemical composition of the stored waste and the technical characteristics of the storage [Baldwin et al., 1995].

Underground waters are almost everywhere in the storage area of the dust-like zinc and iron containing wastes of the electric steel production. The depth of groundwater in the storage area is about 5.0-9.7 m. Quaternary deposits (sands, sandy loams, loams) are the main water-bearing rocks.

Infiltration experiments in the mode of irrigation with a distilled water determined the transformation of components into water-soluble state and their leaching from the waste. Figure 1 shows a scheme of the laboratory setup.

Dissolution of waste components occurs until the chemical potentials of the solvent component in the liquid and solid phases become equal; this shows the metal transition from the dust-like zinc and iron containing wastes. In this case, the reached threshold concentration of the component corresponds to a saturated solution [Baldwin et al., 1995].

A weighed quantity of from the dust-like zinc and iron containing wastes was placed in a filtration column and the infiltration was performed through the waste layer with distilled waters with predetermined $\mathrm{pH}$ values.

Water acidity was the same as in natural atmospheric precipitation in Cherepovets. Since the precipitations are bicarbonate-sulphate, the $\mathrm{pH}$ of distilled water was brought to the set values of a weak sulphuric acid. Infiltration speed was set according to the intensity of precipitation. Timing and sampling started with the income of infiltration waters into a glass.

\section{RESULTS AND DISCUSSIONS}

The obtained infiltration solutions were analysed for the presence of iron, zinc, lead, cadmium, copper, manganese, and strontium since they are the main components of the studied dusts, potentially toxic for the environment. Figures $2-7$ show changes in the studied element concentrations depending on the contact time of the waste sample with the infiltration waters.
The obtained dependences of element concentration on the contact time allow concluding that the lower is $\mathrm{pH}$ of the filtration solution, the higher are heavy metal concentrations in the infiltration waters. All the dependencies show that metal concentrations increase in the infiltration waters in the first 2-6 hours and come to the highest values. This occurs because of the dissolution of the basic waste compounds and metal leaching, followed by reduction of the concentration and achievement of its constant value. Basing on the obtained data, we can state that iron and heavy metals become soluble during water infiltration through the wastes. Formation of hydrogeochemical halos and fluxes of pollution occurs as a result. Following the monitoring data and the

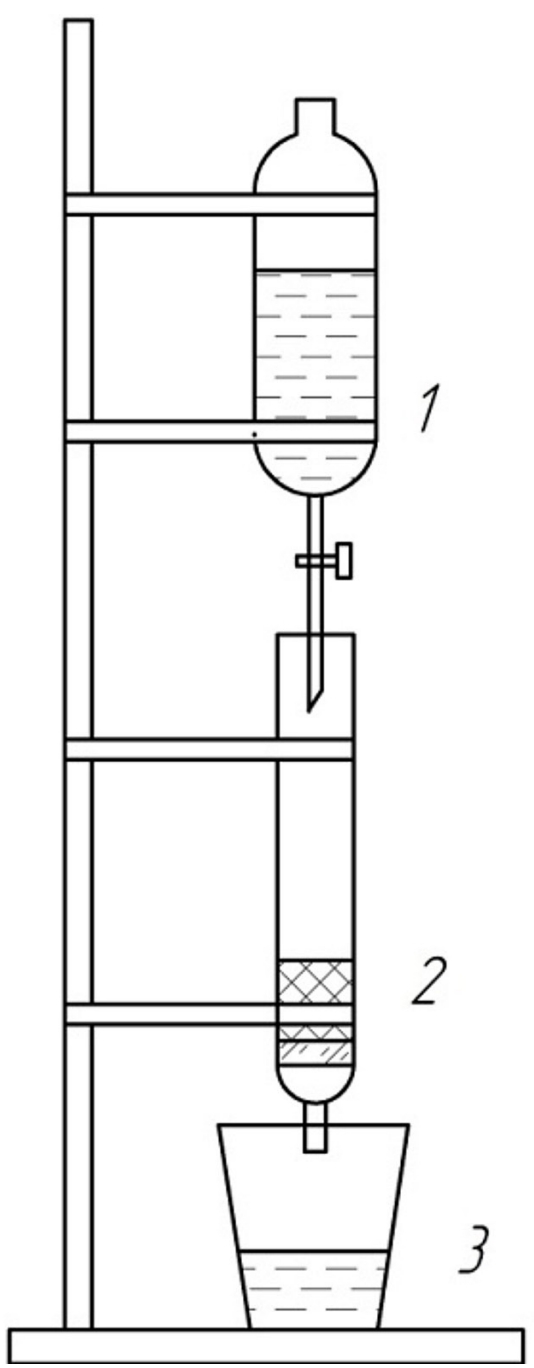

Figure 1. Scheme of the laboratory setup for the infiltration experiment: 1 - a container with the distilled water with a predetermined $\mathrm{pH}$ value; $2-$ a column filled with the investigated waste sample; 3 - a glass with the infiltration water 


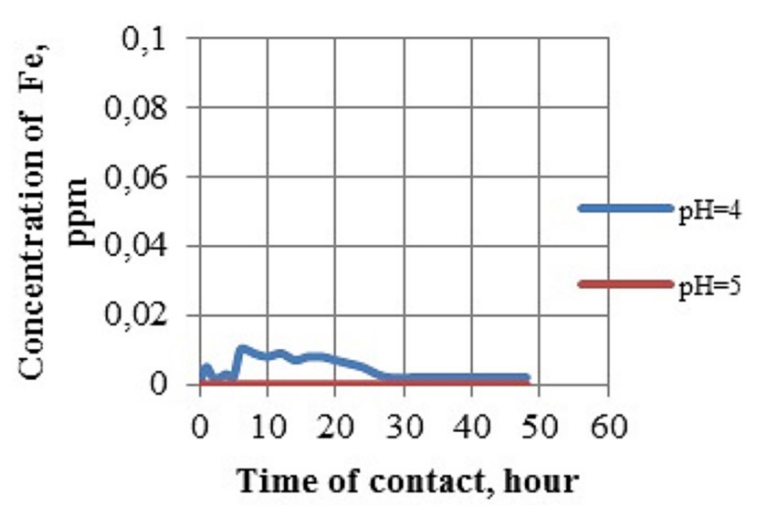

Figure 2. Changing Fe content (the vertical axis, $\mathrm{mg} / \mathrm{dm}^{3}$ ) in the studied solutions depending on the duration of a contact between the filtration water and the sample (the horizontal axis, hours)

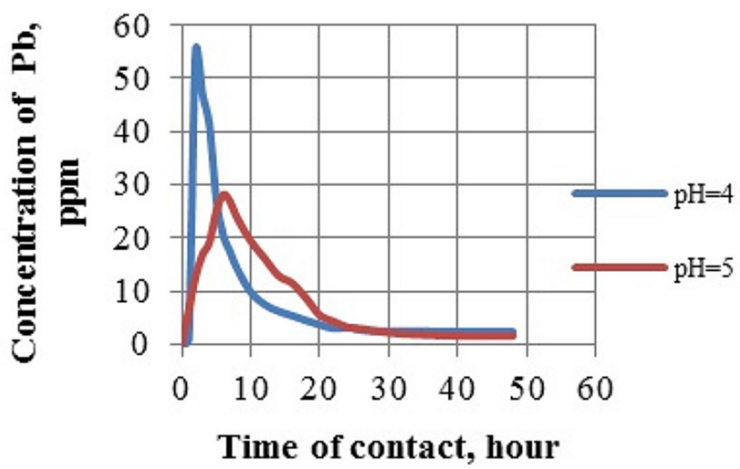

Figure 4. Changing $\mathrm{Pb}$ content (the vertical axis, $\mathrm{mg} / \mathrm{dm}^{3}$ ) in the studied solutions depending on the duration of a contact between the filtration water and the sample (the horizontal axis, hours)

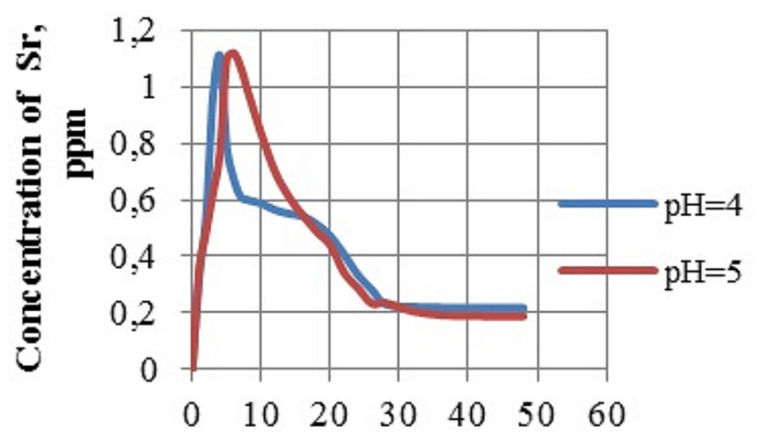

Time of contact, hour

Figure 6. Changing Sr content (the vertical axis, $\mathrm{mg} / \mathrm{dm}^{3}$ ) in the studied solutions depending on the duration of a contact between the filtration water and the sample (the horizontal axis, hours)

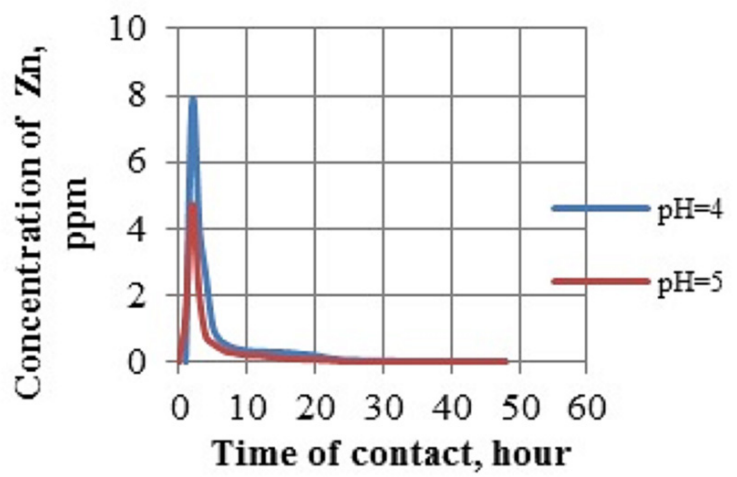

Figure 3. Changing $\mathrm{Zn}$ content (the vertical axis, $\mathrm{mg} / \mathrm{dm}^{3}$ ) in the studied solutions depending on the duration of a contact between the filtration water and the sample (the horizontal axis, hours)

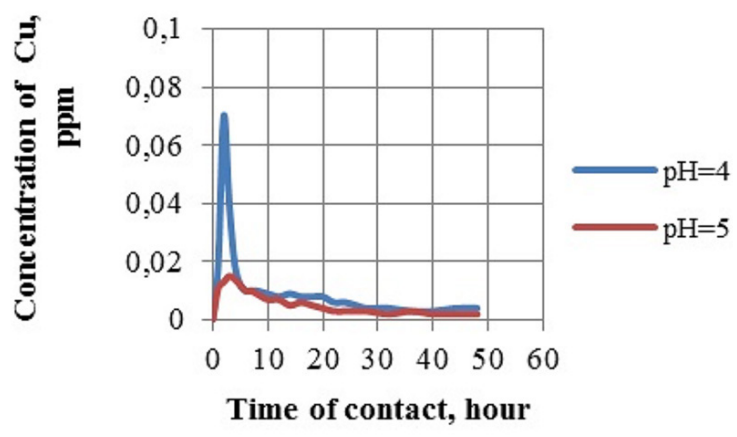

Figure 5. Changing $\mathrm{Cu}$ content (the vertical axis, $\mathrm{mg} / \mathrm{dm}^{3}$ ) in the studied solutions depending on the duration of a contact between the filtration water and the sample (the horizontal axis, hours)

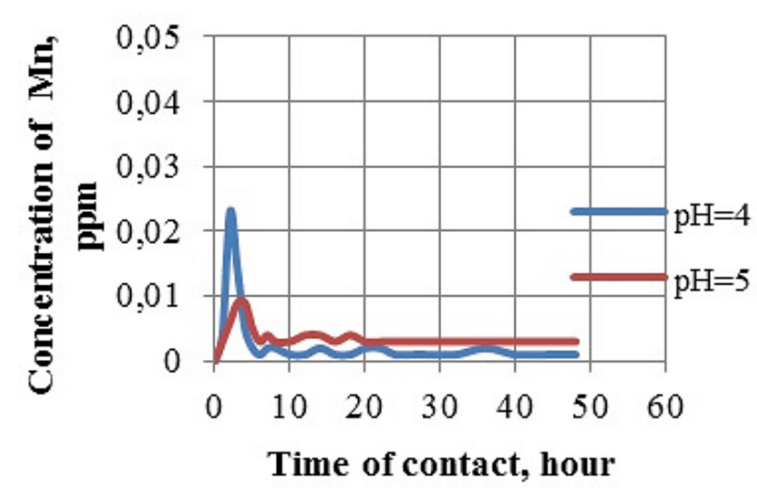

Figure 7. Changing Mn content (the vertical axis, $\mathrm{mg} / \mathrm{dm}^{3}$ ) in the studied solutions depending on the duration of a contact between the filtration water and the sample (the horizontal axis, hours) 
analysis of technical documents, the calculations of geochemical quality characteristics of ground waters were added to the obtained data on the metal solution from the dust-like zinc and iron containing wastes [Fomenko, 2006].

According to the collected data, leaching of waste components with the atmospheric precipitation and migration of iron and heavy metals in ground waters take place with the average, strong, and very strong intensity. It is worth saying that ground waters discharge in the nearby water stream and pollute the Koshta river.

\section{CONCLUSION}

The following conclusions can be done to add together the above-listed data and experimental results:

- accumulation of the dust-like zinc and iron containing wastes imposes the environmental threat;

- the atmo-, lito-, and hydro-geochemical halos of pollution arise;

- with the further action of enterprises and production of the dust-like zinc and iron containing wastes, the environmental impact will grow.

The issue of liquidation of landfills and waste recovery becomes urgent. The choice and implementation of recycling of the considered zinc and iron containing wastes are determined not only by the substance itself, but also by the peculiarities of mining and processing companies, used raw materials, and produced goods.

\section{Acknowledgments}

The analyses were performed using the equipment of the Common Use Centre of Saint Petersburg Mining University.

\section{REFERENCES}

1. Alekseenko, A.V., Pashkevich, M.A., 2016. Novorossiysk agglomeration landscapes and cement production: Geochemical impact assessment. IOP Conference Series: Earth and Environmental Science, 12-50.

2. Alekseenko, V.A., Pashkevich, M.A., Alekseenko A.V., 2017. Metallisation and environmental man-
Table 2. Hydrogeochemical characteristics of the groundwater near the storage of the dust-like zinc and iron containing wastes

\begin{tabular}{|c|c|c|c|}
\hline Element & $\mathrm{Kc}$ & $\mathrm{K}$ & $\Delta \mathrm{l}$ \\
\hline $\mathrm{Fe}$ & 3.5 & 0.54 & 1.33 \\
\hline $\mathrm{Zn}$ & 4.3 & 1.01 & 1.62 \\
\hline $\mathrm{Mn}$ & 4.3 & 0.46 & 1.61 \\
\hline $\mathrm{Cu}$ & 5.0 & 10.81 & 1.89 \\
\hline $\mathrm{Pb}$ & 5.0 & 0.77 & 1.89 \\
\hline
\end{tabular}

$\mathrm{Kc}$ - coefficient of a chemical element accumulation; $\mathrm{K}$ - coefficient of an element aqueous migration; $\Delta \mathrm{l}$ - coefficient of the changing intensity of an element migration in the groundwater as compared with the regional background.

agement of mining site soils. Journal of Geochemical Exploration, 174, 121-127.

3. Baldwin, S.A., Demopoulos, G.P., Papangelakis, V.G., 1995. Mathematical Modelling of the Zinc Pressure Leach Process. Metallurgical and Materials Transaction, 26B, 1035-1047.

4. Beloglazov, I.I., Suslov, A.P. Pedro, A.A., 2014a. Process Control in Ore-Smelting Furnace at Based on Constant Component of the Phase Voltages. Steel in Translation, 44 (12), 901-905.

5. Beloglazov, I.I., Suslov, A.P. Pedro, A.A., 2014b. Change of constant component of phase voltage during melting of zirconium corundum. Tsvetnye Metally, 5, 86-89.

6. Bezel', V.S., Zhuikova, T.V., 2007. Chemical pollution: Transfer of chemical elements to the aboverground phytomass of herbaceous plants. Russian Journal of Ecology, 38 (4), 238-246.

7. Bolshunova, T.S., Rikhvanov, L.P., Mezhibor, A.M., 2014. Epiphytic lichens as indicators of air pollution in Tomsk Oblast (Russia). IOP Conference Series: Earth and Environmental Science, 21 (1), 12-43.

8. Fomenko, A.I., 2006. Scientific substantiation of the technology to utilize dispersed solid wastes of an industrial production. Cherepovets, pp. 411.

9. Jalkanen, H., Oghbasilasie, H., Raipala, K., 2005. Recycling of steelmaking dust - the RADUST concept. Journal of Mining and Metallurgy, 41, 1-16.

10. Lytaeva, T.A., Pashkevich, M.A., 2013. Recycling of the dust from aspiration and gas cleaning systems of steelmaking. Scientific Bulletin of the Moscow State Mining University, 7 (40), 46-50.

11. Machado da Silva, J., Brehm, F.A., 2006. Characterization study of electric arc furnace dust phases. Materials Research, 9 (1), 25-36.

12. Nyirenda, R.L., 1991. The processing of steelmaking flue-dust: a review. Minerals Engineering, 4, 1003-1025. 
13. Pashkevich, M.A., Alekseenko, A. V., Vlasova, E. V., 2015. Biogeochemical and geobotanical assessment of marine ecosystems conditions (Novorossiysk city). Water and Ecology, 2015 (3), 67-80.

14. Rikhanov, L.P. et al., 2011. Trace elements in human organs and tissues and their significance for environmental monitoring. Geochemistry International, 49 (7), 738-742.

15. Roca, N., Pazos, M.S., Bech, J., 2012. Background levels of potentially toxic elements in soils: A case study in Catamarca (a semiarid region in Argentina). Catena, 92, 55-66.

16. State report «State and Protection of the Environment of the Russian Federation», 2015.
17. Timofeev, I.V., Kosheleva, N.E., Kasimov, N.S., Gunin, P.D., Enkh-Amgalan, S., 2016. Geochemical transformation of soil cover in copper-molybdenum mining areas (Erdenet, Mongolia). Journal of Soils and Sediments, 16 (4), 1225-1237.

18. Yaroshenko, Yu.G., 2011. The use of secondary resources of ferrous metallurgy: Problems and solutions. Metallurgical heat engineering, Dnepropetrovsk, 3 (18), 164-176.

19. Zhuikova, T. V. et al., 2015. Specific features of soils and herbaceous plant communities in industrially polluted areas of the Middle Urals. Russian Journal of Ecology, 46 (3), 213-221. 